DOI: https://doi.org/10.31538/ndh.v4i2.351

http://e-journal.ikhac.ac.id/index.php/nidhomulhaq

\title{
PENGARUH BUDAYA ORGANISASI DAN KOMPENSASI TERHADAP KINERJA PENDIDIK DI MADRASAH ALIYAH NAHDLATUL ULAMA MAZRO'ATUL ULUM PACIRAN
}

\author{
Ari Kartiko \\ Jaya Roza Azzukhrufi \\ Institut Pesantren KH. Abdul Chalim \\ E-mail : ari.kartiko5@gmail.com \\ Email; rozarufi123@gmail.com
}

\begin{abstract}
Abstrak
Dalam suatu lembaga pendidikan kontribusi pendidik dilakukan dengan efektif dan berprilaku baik menjadikan sesuatu hal yang penting. Karena setiap pendidik harus mampu memperhatikan secara pasti mana yang menjadi tanggung jawab dan prioritas utamanya dalam rangka mencapai kinerjanya. Budaya organisasi dikatakan kuat apabila sumber daya pendidiknya memiliki nilai inti bersama seperti menjaga hubungan harmonis setiap pendidik. Semakin banyak nilai inti, semakin kuat budayanya, semakin besar pengaruhya terhadap perilaku organisasi dan mudah menjadi fasilitator bagi peningkatan mutu peserta didik dan madrasah. Selain budaya organisasi, kompensasi juga mampu meningkatkan kinerja pendidik secara baik dan maksimal. Kompensasi merupakan sesuatu yang diberikan kepada pendidik sebagai pengganti atas kontribusi jasa yang telah diberikan pendidik pada madrasah. Setiap pendidik dalam suatu madrasah berkeinginan untuk mendapatkan kompensasi yang adil dan layak sesuai dengan harapannya. Oleh karena itu, perlu adanya perhatian yang bersifat terus menerus terhadap pelaksanaan budaya organisasi dan kompensasi, agar pendidik tidak asal dalam menjalankan tugasnya dan pendidik selalu mempunyai ukuran produktif atas kinerjanya. Dalam hal ini peneliti ingin meneliti lebih jauh mengenai budaya organisasi dan kompensasi, MA NU Mazro'atul Ulum Paciran.
\end{abstract}

Kata Kunci : Kinerja Pendidik, Budaya Organisasi, Kompensasi,

\section{Pendidik}

In an educational institution the contribution of educators is done effectively and well behaved makes something important. Because every educator must be able to pay attention to exactly which are his main responsibilities and priorities in order to achieve performance. Organizational culture is said to be strong if its educator resources have a shared core value such as maintaining harmonious relationships of each educator. The more core values, the stronger the culture, the greater the influence on organizational behavior and easy to become a facilitator for improving the quality of students and madrasas. In addition to organizational culture, compensation is also able to improve the performance of educators in 
a good and maximum. Compensation is something given to educators as a substitute for the contribution of services that have been given by educators to madrassas. Every educator in a madrasa wants to get fair and appropriate compensation in accordance with their expectations. Therefore, there needs to be ongoing attention to the implementation of organizational culture and compensation, so that educators do not carelessly carry out their duties and educators always have a productive measure of their performance. In this case the researcher wants to investigate further about organizational culture and compensation, $M A$ NU Marroatul Ulum Paciran.

Keywords: Educator Performance, Organizational culture, Compensation.

\section{PENDAHULUAN}

Dalam suatu lembaga pendidikan kontribusi pendidik dilakukan dengan efektif dan berperilaku baik menjadikan sesuatu hal yang penting. Karena setiap pendidik harus mampu memperhatikan secara pasti mana yang menjadi tanggung jawab dan prioritas utamanya dalam rangka mencapai kinerjanya.

Kinerja menurut Suntoro (1999) adalah suatu hasil kerja yang telah dicapai oleh individu atau sekelompok orang dalam suatu madrasah, dengan mencapai hasil kerja tersebut tidak keluar dari aturan dan norma yang telah ditentukan dalam madrasah dan tanggung jawab masing-masing dalam rangka mencapai tujuan madrasah yang bersangkutan. ${ }^{1}$ Baik buruknya kinerja pendidik kadangkala dipengaruhi oleh faktor internal dan faktor eksternal yang mana keduanya harus diperhatikan oleh

1 Ismail Nawawi Uha, Budaya Organisasi Kepemimpinan Dan Kinerja (Depok: KENCANA, 2017), 213. pihak manajemen madrasah. Faktor internal berhubungan dengan sifat-sifat pendidik dan faktor eksternal berasal dari lingkungan sosial, kepemimpinan, tindakan-tindakan rekan kerja.

Banyak hal yang mempengaruhi kinerja pendidik bekerja secara baik, tanggung jawab, disiplin dan maksimal sehingga menjadi perhatian pihak manajemen madrasah diantaranya yaitu budaya organisasi, dan pemberian kompensasi bagi sumber daya manusia.

Budaya organisasi merujuk pada hubungan yang unik dari norma-norma, nilai-nilai, kepercayaan dan cara berprilaku yang menjadi ciri bagaimana sumber daya pendidik dalam menyelesaikan sesuatu. Budaya organisasi mengandung nilai-nilai yang harus dipahami, dijiwai dan dipraktikan bersama oleh semua pendidik yang terlibat didalamnya, budaya berhubungan dengan bagaimana organisasi membangun komitmen untuk 
mewujudkan visi. Setiap organisasi memiliki budaya organisasi yang berbeda, budaya organisasi tersebut menjadi identitas bagi setiap organisasi. ${ }^{2}$

Budaya organisasi dikatakan kuat apabila sumber daya pendidiknya memiliki nilai inti bersama seperti menjaga hubungan harmonis setiap pendidik. Semakin banyak nilai inti, semakin kuat budayanya, semakin besar pengaruhya terhadap perilaku organisasi dan mudah menjadi fasilitator bagi peningkatan mutu peserta didik dan madrasah. Menurut Ndraha (2010), budaya yang kuat mempunyai 3 ciri, antara lain: kejelasan nilai-nilai dan keyakinan; penyebaran nilai dan keyakinan; kekokohan nilai-nilai inti dan keyakinan. ${ }^{3}$

$$
\text { Budaya organisasi secara }
$$
signifikan sangat berhubungan dengan kinerja pendidik. Pendidik yang sudah memahami keseluruhan nilai-nilai organisasi akan menjadikan nilai-nilai tersebut sebagai suatu kepribadian organisasi. Nilai dan keyakinan tersebut akan menjadi kinerja pendidik.

Selain budaya organisasi, kompensasi juga mampu meningkatkan

\footnotetext{
${ }^{2}$ Uha, 6-7.

${ }^{3}$ Anwar Prabu Mangkunegara, Perilaku Dan Budaya Organisasi, Cetakan Ketiga (Bandung: PT Refika Aditama, 2010), 122.
}

kinerja pendidik secara baik dan maksimal. Diantaranya yaitu pemberian pelatihan, pemberian penghargaan terhadap prestasi yang dicapai pendidik, dan memberikan jam tambah mendidik. Kegiatan tersebut memacu pendidik untuk selalu bekerja dengan lebih semangat dan sesuai dengan tujuan yang ditentukan sebelumnya.

Kompensasi merupakan sesuatu yang diberikan kepada pendidik sebagai pengganti atas kontribusi jasa yang telah diberikan pendidik pada madrasah. Setiap pendidik dalam suatu madrasah berkeinginan untuk mendapatkan kompensasi yang adil dan layak sesuai dengan harapannya. Apabila harapan tersebut terpenuhi, maka pendidik tersebut akan selalu lebih bersemangat dalam bekerja. ${ }^{4}$ Apabila pendidik memandang kompensasi tidak memadai, maka prestasi mendidik, motivasi dan Kepuasan mendidik akan turun secara drastis. Melihat salah satu fungsinya adalah untuk memotivasi pendidik maka madrasah sebagai pihak yang memberikan kompensasi sudah seharusnya memperhatikan secara serius mengenai hal ini. Setiap pendidik yang memberikan kemampuan terbaiknya

4 Sedarmayanti, Manajemen Sumber Daya Manusia (Bandung: Refika Aditama, 2011), 237. 
tentunya harus dibalas dengan hal yang layak. Pihak manajemen madrasah harus memberikan imbalan yang adil dan layak agar pendidik tetap menunjukkan peningkatan kualitas kinerjanya. ${ }^{5}$

Berdasarkan observasi awal di Madrasah Aliyah Nahdlatul Ulama' Mazro'atul Ulum Paciran. Peneliti menemukan masalah-masalah yang berkaitan dengan budaya organisasi dan kompensasi. Adapun masalah mengenai budaya organisasi yang peneliti temukan di madrasah tersebut yaitu kepala madrasah kurang dalam hal mengendalikan, menggerakkan, mengakomodasikan dan menyerasikan pendidik yang berkompeten, sehingga menyebabkan kurangnya hubungan harmonis antar pendidik, ini bisa dilihat dari banyaknya pendidik yang masih mempunyai sifat untuk mengelompok sesuai dengan kenyamanan hati tidak sesuai yang telah di tentukan kepala madrasah. Jikalau terus dibiarkan oleh kepala sekolah sangat mungkin kinerja pendidik akan terus menerus turun kinerjanya. Hal ini berkaitan dengan kurang intensnya pengendalian dan arahan dari kepala madrasah.

5 Mangkunegara, Perilaku Dan Budaya Organisasi, 138.

\section{Kajian Teori}

\section{Kinerja Pendidik}

Kinerja adalah keluaran yang dihasilkan oleh fungsi-fungsi atau indikator-indikator suatu pekerjaan atau suatu profesi dalam waktu tertentu. Kinerja merupakan hasil kerja yang dicapai oleh seorang pendidik dalam melaksanakan tugasnya sesuai dengan tanggungjawab yang diberikan kepadanya. ${ }^{6}$ Menurut Pabundu kinerja adalah hasil-hasil fungsi pekerjaan/kegiatan seseorang atau kelompok dalam suatu organisasi yang dipengaruhi oleh berbagai faktor untuk mencapai tujuan organisasi dalam periode waktu tertentu.

Menurut Abudin Nata (1997) Pendidik adalah orang yang melakukan kegiatan dalam bidang mendidik. Pendidik adalah orang yang sengaja mempengaruhi peserta didik untuk mencapai tingkat kesempurnaan menjadi manusia yang lebih tinggi. ${ }^{8}$

Dalam Undang-undang Republik Indonesia No.14 tahun 2005 dijelaskan

${ }^{6}$ Uha, Budaya Organisasi Kepemimpinan Dan Kinerja, 213.

7 Pabundu, Budaya Organisasi Dan Peningkatan Kinerja Karyawan (Jakarta: Bumi Aksara, 2010), 121.

8 A. Fatah Yasin, Dimensi-Dimensi Pendidikan Islam (malang: UIN-Malang Pers, 2008), 68. 
bahwa: "guru mempunyai kedudukan sebagai tenaga profesional pada jenjang pendidikan usia dini, pendidikan dasar, dan pendidikan menengah, pada jalur pendidikan formal yang diangkat sesuai dengan peraturan perundang-undangan. Lebih lanjut disebutkan bahwa: "guru wajib memiliki kualifikasi akademik, kompetensi, sertifikasi pendidik, sehat jasmani dan rohani, serta memiliki kompetensi untuk mewujutkan tujuan pendidikan nasional. ${ }^{9}$

kinerja pendidik merupakan hasil kerja, baik dalam bentuk dokumen, maupun efek dari proses pembelajaran yang berkembang dalam diri peserta didik sebagai bagian dari proses belajar mengajar. Dalam pelaksanaannya, seorang pendidik memainkan peran dalam proses pendewasaan peserta didik sebagai pembimbing dan pelatih juga dalam proses belajar mengajar.

\section{Faktor-faktor Kinerja}

Wibowo (2012) faktor-faktor yang mempengaruhi kinerja adalah:

1. Personal factor, ditunjukan oleh tingkat keterampilan, kompetensi yang dimiliki, motivasi dan komitmen individu.
2. Leadership factor, ditentukan oleh kualitas dorongan, bimbingan, dan dukungan yang dilakukan manajer dan team leader.

3. Team factor, ditunjukan oleh kualitas dukungan yang diberikan oleh rekan sekerja.

4. System factor, ditunjukan oleh adanya sistem kerja dan fasilitas yang diberikan oleh organisasi.

5. Contextual/situational

factor, ditunjukkan oleh tingginya tingkat tekanan dan perubahan lingkungan internal dan eksternal. ${ }^{10}$

Mangkunegara (2007), Ada dua faktor yang mempengaruhi kinerja yaitu:

1) Faktor Individu

Secara psikologis, individu yang normal adalah individu yang memiliki integritas yang tinggi antara fungsi psikis (rohani) dan fisiknya (jasmani). Dengan adanya integritas yang tinggi antara fungsi psikis dan fisik maka individu tersebut memiliki konsentrasi diri yang baik. Konsentrasi yang baik ini merupakan modal utama individu manusia untuk mampu mengelola dan mendayagunakan

${ }^{10}$ Wibowo, Manajemen Kinerja (Jakarta: PT

${ }^{9}$ Undang-Undang Republik Indonesia No.14 tahun 2005 tentang Guru dan Dosen

\section{Raja Grafindo Persada, 2012), 100.}


potensi dirinya secara optimal dalam melaksanakan kegiatan atau aktivitas kerja sehari-hari dalam mencapai tujuan organisasi.

2) Faktor Lingkungan Organisasi Faktor lingkungan kerja organisasi sangat menunjang bagi individu dalam mencapai kinerja. Faktor lingkungan organisasi yang dimaksud antara lain uraian jabatan yang jelas, otoritas yang memadai, target kerja yang menantang, pola komunikasi yang efektif, hubungan kerja yang harmonis, iklim kerja yang respek dan dinamis, peluang berkarir dan fasilitas kerja yang relatif memadai. ${ }^{11}$

\section{Tugas dan Fungsi Pendidik}

Djamarah (2000) mengemukakan bahwa tugas dan tanggung jawab pendidik adalah sebagai:

a. Korektor, yaitu pendidik bisa membedakan mana nilai yang baik dan mana nilai yang buruk, koreksi yang dilakukan bersifat menyeluruh dari afektif sampai psikomotor.

11 Anwar Prabu Mangkunegara, Evaluasi Kinerja Sumber Daya Manusia (Bandung: Refika Aditama, 2007), 13-14. b. Inspirator, yaitu pendidik menjadi inspirator/ilham bagi kemajuan belajar siswa / mahasiswa, petunjuk bagaimana belajar yang baik, dan mengatasi permasalahan lainnya.

c. Informator, yaitu pendidik harus dapat memberikan informasi perkembangan ilmu pengetahuan dan teknologi

d. Organisator, yaitu pendidik harus mampu mengelola kegiatan akademik (belajar).

e. Motivator, yaitu pendidik harus mampu mendorong peserta didik agar bergairah dan aktif belajar.

f. Inisiator, yaitu pendidik menjadi pencetus ide-ide kemajuan dalam pendidikan dan pengajaran.

g. Fasilitator, yaitu pendidik dapat memberikan fasilitas yang memungkinkan kemudahan kegiatan belajar.

h. Pembimbing, yaitu pendidik harus mampu membimbing anak didik manusia dewasa yang cakap.

i. Demonstrator, yaitu jika diperlukan pendidik bisa mendemonstrasikan bahan pelajaran yang susah difahami.

j. Pengelola kelas, yaitu pendidik harus mampu mengelola kelas 
untuk menunjang interaksi berpengaruh terhadap lingkugan dan edukatif.

k. Mediator, yaitu pendidik menjadi media yang berfungsi sebagai alat komunikasi guna mengefektifkan proses interaktif edukatif.

1. Supervisor, yaitu pendidik hendaknya dapat memperbaiki, dan menilai secara kritis terhadap proses pengajaran.

m. Evaluator, yaitu pendidik dituntut menjadi evaluator yang baik dan jujur. $^{12}$

\section{Teori Budaya Organisasi}

Budaya merupakan produk dari suatu komunitas, terdiri dari nilai-nilai yang diyakini dan dijalankan oleh individu dalam suatu organisasi dan dijadikan perekat, pedoman dalam kehidupan serta pemecahan masalah. Budaya juga merupakan pembeda antara suatu organisasi dalam memahami masyarakat dan kelompok manusia untuk waktu yang tidak sementara. Budaya yang kuat juga bisa dimaknakan sebagai budaya yang dipegang secara insentif, secara luas dianut dan semakin disosialisasikan dan diwariskan dapat

\footnotetext{
${ }^{12}$ Yasin, $82-83$
}

Organisasi adalah suatu wadah bagi kelompok yang menghimpun anggota-anggotanya, memiliki satu tujuan tertentu dan bekerja sama mencapai tujuan yang telah ditetapkan. ${ }^{14}$ Didalam kelompok tersebut memiliki struktur yang memuat unit-unit kerja sebagai pengelompokan tugas-tugas atau pekerjaan sejenis dari yang mudah hingga yang terberat, setiap unit memiliki kapasitas dan beban kerja yang harus diwujudkan untuk mencapai tujuan yang telah ditetapkan. Dalam pencapaian tujuan tersebut dibutuhkan koordinasi dalam pelaksanaan kerjasama yang berdasarkan prosedur yang telah diatur secara formal.

Budaya organisasi adalah nilainilai yang menjadi pegangan sumber daya manusia dalam menjalankan kewajiban dan perilakunya di dalam organisasi. ${ }^{15} \quad$ Robbins menjelaskan, ada lima fungsi budaya organisasi yang sangat penting untuk kemajuan organisasi, yaitu: a) Budaya

13 Taliziduhu Ndraha, Budaya Organisasi (Jakarta: PT Rineka Cipta, 2004), 12.

14 Adam Ibrahim Indrawijaya, Teori, Perilaku, Dan Budaya Organisasi (Bandung: PT Refika Aditama, 2010), 9.

${ }^{15}$ Uha, Budaya Organisasi Kepemimpinan Dan Kinerja, 5. 
berperan sebagai batas-batas penentu. Budaya menciptakan perbedaan antara satu organisasi dengan organisasi yang lain. Misalnya gaya kepemimpinan otoriter menimbulkan budaya kerja yang disiplin. b) Mengantarkan suatu perasaan identitas bagi anggota organisasi untuk memahami visi, misi, dan tujuan dari organisasi. Misalnya kebanggan sumber daya manusia atas status pekerjaan yang diperolehnya. c) Mempermudah timbulnya komitmen yang lebih luas daripada kepentingan individual seseorang. Misalnya sumber daya manusia yang berkontribusi penuh pada organisasi. d) Meningkatkan stabilitas sistem sosial karena merupakan perekat sosial yang membantu mempersatukan organisasi. Misalnya adanya rasa solidaritas sumber daya manusia dalam pemecahan masalah. e) Sebagai mekanisme kontrol dan rasional yang memandu dan membentuk sikap serta perilaku karyawan. Misalnya sumber daya manusia yang mengikuti norma-norma yang berlaku di organisasi. ${ }^{16}$

\footnotetext{
16 Usmany, Tiara Putri. Dkk. Pengaruh Budaya Organisasi Terhadap Komitmen Organisasional dan Kinerja Karyawan. Malang: Jurnal Administrasi Bisnis. Vol. 37, No. 2. 2016 , hal. 41
}

\section{Teori Kompensasi}

Kompensasi adalah segala sesuatu pendapatan yang berbentuk barang langsung atau tidak langsung yang diterima oleh individu sebagai imbalan atas jasa yang diberikan kepada organisasi. Menurut Gary Dessler, kompensasi karyawan adalah setiap bentuk pembayaran atau imbalan yang diberikan kepada karyawan karena telah bekerja. ${ }^{17}$ Hal tersebut menjadikan kompensasi menjadi bentuk pembayaran dalam bentuk manfaat dan insentif untuk memotivasi karyawan agar produktivitas kerja semakin meningkat. Pembentukan sistem kompensasi yang efektif merupakan bagian penting dari manajemen sumber daya manusia karena membantu menarik dan mempertahankan pekerjaan. ${ }^{18}$

Dalam sebuah lembaga pendidikan pasti memiliki tujuan untuk mencapai tujuan tersebut, seperti halnya pemberian kompensasi. Tujuan dari pemberian kompensasi antara lain menghargai kinerja, menjamin keadilan,

17 Gary Dessler, Manajemen Sumber Daya Manusia, 14th ed. (Jakarta: salemba empat, 2017).

18 Zain Ikhwani Jihadi Robirodia and Eka Prihatin, "Pengaruh Kompensasi Dan Iklim Organisasi Sekolah Terhadap Kepuasan Kerja Guru Non PNS Madrasah Aliyah," Jurnal Administrasi Pendidikan 23, no. 1 (2016): 15. 
mempertahankan pendidik, memperoleh pendidik yang bermutu, mengendalikan biaya, memenuhi peraturan. ${ }^{19}$

Tujuan pemberian kompensasi menurut Malayu Hasibuan (2005) sebagai berikut:

1) Ikatan kerjasama. Terjalinnya ikatan kerjasama yang baik antara kepala madrasah dengan pendidik salah satunya dengan pemberian kompensasi yang adil dan layak bagi pendidik.

2) Kepuasan kerja. Kepuasan kerja didapat oleh setiap pendidik jikalau pemberian kompensasi berupa uang, materil dan benda sesuai dengan kebutuhan fisik. Begitupun dengan status sosial yang diperhatikan penuh oleh kepala sekolah.

3) Pengadaan efektif. Jika kepala madrasah semakin memerhatikan sistem kompensasi secara adil dan layak, maka pengadaan sumber daya pendidik yang sanggup kontribusi kepada madrasah semakin mudah didapat.

4) Motivasi. Kompensasi juga ikut andil dalam memotivasi pendidik yang tingkat produktivitasnya tinggi.

${ }^{19}$ Sedarmayanti, Manajemen Sumber Daya Manusia, 239.
5) Stabilitas karyawan. Apabila kepala madrasah mampu dalam mengatur dan mengelola pemberian kompensasi terhadap pendidik makan kestabilitasan karyawan lebih terjamin.

6) Disiplin. Terciptannya kedisiplinan pendidik juga dipengaruhi bagaimana kepala madrasah dalam memberikan kompensasi terhadap pendidik-pendidiknya.

7) Pengaruh serikat buruh. Pengaruh serikat buruh terhadap sumber daya yang teredia dapat dihindarkan oleh setiap pemimpin dengan mengetahui dan memahami sistem kompensasi. Dan sumber daya manusia juga akan berkonsentrasi penuh pada pekerjaanya yang dijabatnya.

8) Pengaruh pemerintah. Intervensi pemerintah dapat dihindarkan manakala program kompensasi sesuai dengan Undang-undang perburuhan yang berlaku. ${ }^{20}$

${ }^{20}$ Malayu Hasibuan, Manajemen Sumber Daya Manusia (Jakarta: Bumi Aksara, 2005), 112. 
Adapun asas-asas pemberian kompensasi menurut Hasibuan (2005) antara lain:

1) Asas Adil

Besar dan kecilnya suatu kompensasi yang diberikan kepada setiap pendidik harus disesuaikan dengan apa yang telah dicapai pendidik yaitu prestasi kerja dan memperhatikan tingkat jabatan atau jenis pekerjaannya, dan tanggung jawab pendidik terhadap pekerjaan yang telaj diberikan. Jadi adil dalam hal ini tidak harus disamakan antar setiap pendidik.

2) Asas Layak dan Wajar

Pemberian kompensasi oleh kepala madrasah yang di terima oleh pendidik dapat memenuhhi kebutuhannya pada tingkat normative yang ideal. Relatif menjadi barometer asas layak, penetapan kompensasi didasarkan atas upah minimal pemerintah yang berlaku. ${ }^{21}$

2. Hipotesis dan Kerangka Pemikiran

a. Terdapat pengaruh antara budaya organisasi dan kompensasi terhadap kinerja

\footnotetext{
${ }^{21}$ Hasibuan, 129.
}

pendidik di MA NU

Mazro’atul Ulum Paciran.

b. Terdapat pengaruh signifikan dan positif, serta budaya organisasi yang paling dominan terhadap kinerja pendidik di MA NU Mazro’atul Ulum Paciran.

Berdasarkan dari konsepkonsep dan landasan teori yang telah dijelaskan sebelumnya, selanjutnya disusunlah kerangka pemikiran yang disajikan pada bagan dibawah ini:

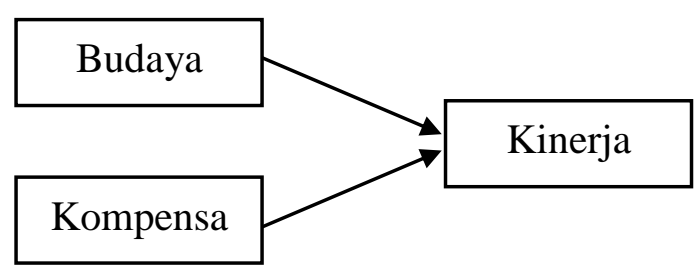

\section{Hasil dan Pembahasan}

Sampel

Sampel yang dijadikan penelitian ini adalah seluruh tenaga pendidik yang tergabung dalam struktur organisasi madrasah di MA NU Mazro'atul Ulum Paciran yang berjumlah 25 orang. Karakteristik Responden

\section{Jenis Kelamin}

Deskripsi karakteristik responden berdasarkan jenis kelamin disajikan dalam tabel di bawah ini: 
Tabel 1

Identitas Responden

Berdasarkan Jenis Kelamin

\begin{tabular}{lcc}
\hline $\begin{array}{c}\text { Jenis } \\
\text { Kelamin }\end{array}$ & Frekuensi & $\begin{array}{c}\text { Persent } \\
\text { ase (\%) }\end{array}$ \\
\hline Laki-laki & 19 & 76 \\
Pr & 6 & 24 \\
Jumlah & $\mathbf{2 5}$ & $\mathbf{1 0 0}$ \\
\hline
\end{tabular}

Berdasarkan tabel 1, dapat dilihat bahwa mayoritas responden yaitu pendidik laki-laki sebanyak 19 orang $(76 \%)$ dan sisanya perempuan sebanyak 6 orang (24\%).

Usia

Deskripsi karakteristik responden berdasarkan usia disajikan pada dalam tabel dibawah ini:

\section{Identitas Responden \\ Berdasarkan Usia}

Usia Frekuensi Persentase

\begin{tabular}{lcc} 
& & $\mathbf{( \% )}$ \\
\hline $\mathbf{2 0 - 3 0}$ & 3 & 12 \\
$\mathbf{3 1 - 4 0}$ & 19 & 76 \\
$\mathbf{4 1 - 4 5}$ & 0 & 0 \\
$>\mathbf{4 5}$ & 3 & 12 \\
Jumlah & $\mathbf{2 5}$ & $\mathbf{1 0 0}$ \\
\hline
\end{tabular}

Berdasarkan tabel 2, dapat dilihat bahwa mayoritas responden usia $\quad 31-40$ sebanyak 19 orang (76,0\%), 20-30 sebanyak 3 orang (12\%), $\quad>\quad 45$ sebanyak 3 orang (12\%), dan usia 41-45 sebanyak 0 orang.

\section{Pendidikan Terakhir}

Deskripsi karakteristik responden berdasarkan pendidikan terakhir disajikan pada dalam tabel dibawah ini.

Tabel 3

Identitas Responden

Berdasarkan Pendidikan

Terakhir

\begin{tabular}{ccc}
\hline Pendidika & Frekuen & Persentas \\
n & si & e $(\%)$
\end{tabular}

Terakhir

Tabel 2 S-1 $17 \quad 68$

S-2 624

Diploma 2

\section{$1 / 2 / 3$}

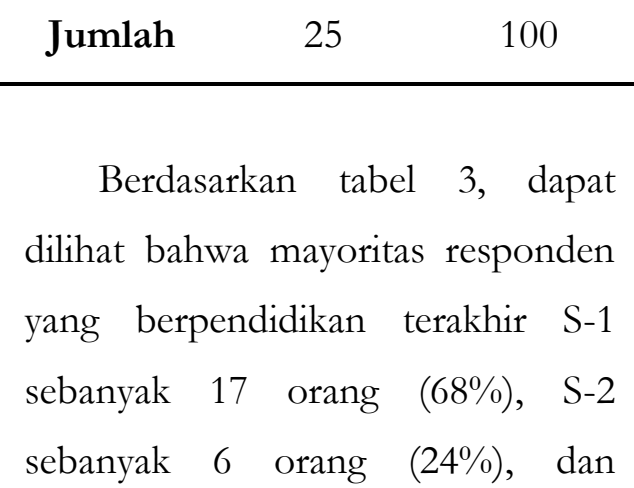


Diploma 1/2/3 sebanyak 2 orang $(8 \%)$.

\section{Status Pendidik}

Deskripsi

karakteristik

responden berdasarkan status pendidik disajikan pada dalam tabel dibawah ini:

\section{Tabel 4}

Identitas Responden

Berdasarkan Status Pendidik

\begin{tabular}{|c|c|c|}
\hline Status Pendidik & Frekuensi & $\begin{array}{c}\text { Perse } \\
\text { ntase } \\
(\%)\end{array}$ \\
\hline $\begin{array}{l}\text { GTY (Guru Tetap } \\
\text { Yayasan) }\end{array}$ & 25 & 100 \\
\hline $\begin{array}{l}\text { GTT (Guru Tidak } \\
\text { Tetap) }\end{array}$ & 0 & 0 \\
\hline Jumlah & 25 & 100 \\
\hline
\end{tabular}

Berdasarkan tabel 4, dapat dilihat bahwa responden status pendidik semuanya GTY (Guru Tetap Yayasan) sebanyak 25 orang (100\%). Sedangkan GTT (Guru Tidak Tetap) tidak ada (0)

\section{Lama Bekerja Sebagai Pendidik}

$$
\text { Deskripsi karakteristik }
$$
responden berdasarkan lama bekerja sebagai pendidik disajikan pada dalam tabel dibawah ini:
Tabel 5

Identitas Responden Berdasarkan Lama Bekerja

\begin{tabular}{ccc}
\hline $\begin{array}{c}\text { Lama } \\
\text { Bekerja }\end{array}$ & Frekuensi & $\begin{array}{c}\text { Persentase } \\
\mathbf{( \% )}\end{array}$ \\
\hline 0-2 tahun & 4 & 16 \\
2-5 tahun & 5 & 20 \\
5-8 tahun & 9 & 36 \\
$>$ 9 tahun & 7 & 28 \\
Jumlah & 25 & 100 \\
\hline
\end{tabular}

Berdasarkan tabel 5, dapat dilihat bahwa responden lama bekerja sebagai pendidik 0-2 tahun sebanyak 4 orang (16\%), 2-5 tahun sebanyak orang (20\%), 5-8 tahun sebanyak 9 orang (36\%), dan $>9$ tahun sebanyak 7 orang $(28 \%)$.

Metode Statistik

Untuk pengolahan data menggunakan program (SPSS Versi 24) Jumlah responden populasi penelitian ini adalah tenaga pendidik di MA NU Mazro'atul Ulum Paciran yang berjumlah 25 orang.

\section{Hasil Penelitian}

1. Uji Validitas dan Reliabilitas 
Tabel 6

Uji Validitas Variabel $\mathbf{X}_{1}$ (Budaya Organisasi)

\begin{tabular}{cccc}
\hline Pertanyaan & $\mathbf{r}$ & $\mathbf{r}_{\text {Tabel }}$ & Keterangan \\
& Hitung & & \\
\hline $\mathbf{X 1 . 1}$ & 0.530 & 0.396 & Valid \\
$\mathbf{X 1 . 2}$ & 0.566 & 0.396 & Valid \\
$\mathbf{X 1 . 3}$ & 0.516 & 0.396 & Valid \\
$\mathbf{X 1 . 4}$ & 0.497 & 0.396 & Valid \\
$\mathbf{X 1 . 5}$ & 0.453 & 0.396 & Valid \\
$\mathbf{X 1 . 6}$ & 0.502 & 0.396 & Valid \\
$\mathbf{X 1 . 7}$ & 0.550 & 0.396 & Valid \\
$\mathbf{X 1 . 8}$ & 0.740 & 0.396 & Valid \\
$\mathbf{X 1 . 9}$ & 0.712 & 0.396 & Valid \\
$\mathbf{X 1 . 1 0}$ & 0.704 & 0.396 & Valid \\
$\mathbf{X 1 . 1 1}$ & 0.696 & 0.396 & Valid \\
$\mathbf{X 1 . 1 2}$ & 0.617 & 0.396 & Valid \\
$\mathbf{X 1 . 1 3}$ & 0.502 & 0.396 & Valid \\
$\mathbf{X 1 . 1 4}$ & 0.550 & 0.396 & Valid \\
\hline
\end{tabular}

Sumber: Hasil pengolahan kuesioner menggunakan SPSS versi 24

Berdasarkan data pada tabel 6 uji validitas variabel $\mathrm{X}_{1}$ (Budaya Organisasi) diatas, dengan $r_{\text {hitung }}>r$ tabel (diketahui bahwa nilai pada $\mathrm{r}$ tabel sebesar 0.396 pada jumlah 25 $(\mathrm{n}=25) \mathrm{df}=(\mathrm{n}-2)(25-2)=23)$, berdasarkan data pada tabel 4.6 diatas, ada 14 pertanyaan pada variabel $\mathrm{X}_{1} \quad$ (Budaya Organisasi) dinyatakan valid, karena $\mathrm{r}_{\text {hitung }}>\mathrm{r}$ tabel.

Tabel 7

Uji Validitas Variabel $\mathbf{X}_{2}$ (Kompensasi)

\begin{tabular}{cccc}
\hline Pertanyaan & $\mathbf{r}$ & $\mathbf{r}_{\text {Tabel }}$ & Keterangan \\
& Hitung & \\
\hline $\mathbf{X 2 . 1}$ & 0.682 & 0.396 & Valid \\
$\mathbf{X 2 . 2}$ & 0.719 & 0.396 & Valid \\
$\mathbf{X 2 . 3}$ & 0.673 & 0.396 & Valid \\
$\mathbf{X} 2.4$ & 0.500 & 0.396 & Valid \\
$\mathbf{X 2 . 5}$ & 0.527 & 0.396 & Valid \\
$\mathbf{X 2 . 6}$ & 0.562 & 0.396 & Valid \\
$\mathbf{X 2 . 7}$ & 0.402 & 0.396 & Valid \\
$\mathbf{X 2 . 8}$ & 0.525 & 0.396 & Valid \\
$\mathbf{X 2 . 9}$ & 0.471 & 0.396 & Valid \\
$\mathbf{X 2 . 1 0}$ & 0.538 & 0.396 & Valid \\
$\mathbf{X 2 . 1 1}$ & 0.466 & 0.396 & Valid \\
\hline
\end{tabular}

Sumber: Hasil pengolahan kuesioner menggunakan SPSS versi 24

Berdasarkan data pada tabel 7 uji validitas variabel $\mathrm{X}_{2}$ (Kompensasi) diatas, dengan $\mathrm{r}_{\text {hitung }}$ $>r_{\text {tabel }}$ (diketahui bahwa nilai pada $r$ tabel sebesar 0.396 pada jumlah 25 $(\mathrm{n}=25) \quad \mathrm{df}=(\mathrm{n}-2)(25-2)=23)$, berdasarkan data pada tabel 4.7 diatas, ada 11 pertanyaan pada variabel $\quad \mathrm{X}_{2} \quad$ (Kompensasi) 
dinyatakan valid, karena $r_{\text {hitung }}>r$ tabel.

Tabel 8

Uji Validitas Variabel Y (Kinerja Pendidik)

\begin{tabular}{cccc}
\hline Pertanyaan & $\mathbf{r}$ & $\mathbf{r}_{\text {Tabel }}$ & Keterangan \\
& Hitung & & \\
\hline Y1.1 & 0.467 & 0.396 & Valid \\
Y1.2 & 0.880 & 0.396 & Valid \\
Y1.3 & 0.713 & 0.396 & Valid \\
Y1.4 & 0.777 & 0.396 & Valid \\
Y1.5 & 0.533 & 0.396 & Valid \\
Y1.6 & 0.525 & 0.396 & Valid \\
Y1.7 & 0.515 & 0.396 & Valid \\
Y1.8 & 0.593 & 0.396 & Valid \\
Y1.9 & 0.429 & 0.396 & Valid \\
Y1.10 & 0.636 & 0.396 & Valid \\
Y1.11 & 0.555 & 0.396 & Valid \\
Y1.12 & 0.761 & 0.396 & Valid \\
Y1.13 & 0.599 & 0.396 & Valid \\
Y1.14 & 0.709 & 0.396 & Valid \\
\hline
\end{tabular}

Sumber: Hasil pengolahan kuesioner menggunakan SPSS versi 24

Berdasarkan data pada tabel 8 uji validitas variabel $\mathrm{Y}$ (Kinerja Pendidik) diatas, dengan $r_{\text {hitung }}>r$ tabel (diketahui bahwa nilai pada $r$ tabel sebesar 0.396 pada jumlah 25 $(\mathrm{n}=25) \mathrm{df}=(\mathrm{n}-2)(25-2)=23)$, berdasarkan data pada tabel 4.8 diatas, ada 14 pertanyaan pada variabel Y (Kinerja Pendidik) dinyatakan valid, karena $\mathrm{r}_{\text {hitung }}>\mathrm{r}$ tabel.

\section{Tabel 9}

Uji Reliabilitas Variabel $\mathbf{X}_{1}$ (Budaya Organisasi)

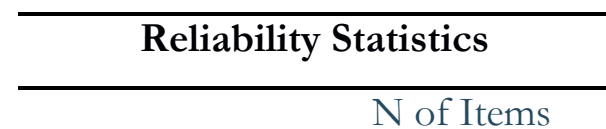

Cronbach's Alpha

0.841 14

Sumber: Hasil pengolahan kuesioner menggunakan SPSS

versi 24

Berdasarkan data pada tabel 9 uji reliabilitas pada variabel $\mathrm{X}_{1}$ (Budaya Organisasi) diatas, dapat dilihat bahwa nilai Cronbach's Alpha pada tabel diatas sebesar 0,841 dari 14 pertanyaan pada variabel $\mathrm{X}_{1}$, sehingga dapat dinyatakan bahwa tingkat reliabilitasnya reliable, karena nilai $>0,6(0,841>0,6)$ Dengan demikian, pertanyaan pada variabel $\mathrm{X}_{1} \quad$ Budaya Organisasi) memiliki tingkat 
konsistensi yang baik dan dapat dipercaya.

Tabel 10

Uji Reliabilitas Variabel $\mathbf{X}_{2}$ (Kompensasi)

$\frac{\text { Reliability Statistics }}{\text { N of Items }}$

Cronbach's

Alpha

0.755

Sumber: Hasil pengolahan kuesioner menggunakan SPSS versi 24

Berdasarkan data pada tabel 10 uji reliabilitas pada variabel $\mathrm{X}_{2}$ (Kompensasi) diatas, dapat dilihat bahwa nilai Cronbach's Alpha pada tabel diatas sebesar 0,755 dari 11 pertanyaan pada variabel $\mathrm{X}_{2}$, sehingga dapat dinyatakan bahwa tingkat reliabilitasnya reliable, karena nilai $>0,6 \quad(0,755>0,6)$. Dengan demikian, pertanyaan pada variabel $\mathrm{X}_{2}$ (Kompensasi) memiliki tingkat konsistensi yang baik dan dapat dipercaya.
Tabel 11

Uji Reliabilitas Variabel Y

(Kinerja Pendidik)

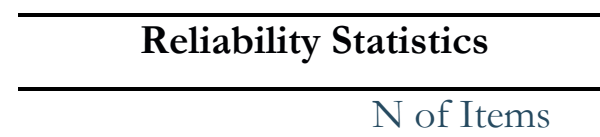

Cronbach's

Alpha

0.877 14

Sumber: Hasil pengolahan kuesioner menggunakan SPSS versi 24

Berdasarkan data pada tabel 11 uji reliabilitas pada variabel $\mathrm{Y}$ (Kinerja Pendidk) diatas, dapat dilihat bahwa nilai Cronbach's Alpha pada tabel diatas sebesar 0,877 dari 14 pertanyaan pada variabel $\mathrm{Y}$, sehingga dapat dinyatakan bahwa tingkat reliabilitasnya reliable, karena nilai $>0,6(0,877>0,6)$ Dengan demikian, pertanyaan pada variabel Y (Kinerja Pendidk) memiliki tingkat konsistensi yang baik dan dapat dipercaya.

\section{Uji Hipotesis}

Untuk mengetahui apakah model summary diatas sudah benar atau salah, diperlukan uji hipotesis (Uji-F). Uji hipotesis menggunakan angka F 
sebagaimana tertera dalam tabel

hasil dari SPSS dibawah ini:

Tabel 12

Uji Hipotesis (ANOVA)

responden - jumlah variabel atau 25

$-3=22$, dengan ketentuan tersebut, diperoleh angka $\mathrm{F}$ tabel sebesar 3,44.

Dari hasil penghitungan

Mean didapatkan Sif. penelitian sebesar Square 43,099 > Ftabel sebesar 3,44

2

349.483 sehingga disimpulkan bahwasannya 0ada pengaruh yang

8.109 secara bersamaan signifikan budaya organisasi dan kompensasi terhadap kinerja pendidik. dengan demikian, uji koefisien determinasi diatas a. Dependent Variable: Kinerja Pendidik b. Predictors: (Constant), Kompensasi, Budaya Organisudiah layak dan benar. Besarnya

Sumber: Hasil pengolahan

kuesioner menggunakan SPSS

versi 24

Dalam pengujian ini peneliti akan melakukan dengan dua cara. Pertama, dengan membandingkan besarnya angka $F$ penelitian dengan F tabel. kedua, dengan cara membandingkan angka taraf signifikansi (sig) hasil penghitungan dengan taraf signifikansi 0,05 (5\%).

Dapat dilihat F penelitian dari SPSS sebesar 43,099, sedangkan F tabel harus menghitung terlebih dahulu dengan ketentuan Derajat Kebebasan (DK) dengan ketentuan numerator: jumlah variabel -1 atau $3-1=2$; dan denumeter: Jumlah pengaruh ialah 79,7\%. Besarnya pengaruh variabel lain diluar model tersebut dihitung dengan rumus: 1 $\mathrm{R}^{2}$ atau $1-0,797=0,203$ atau sebesar 20,3\%.taraf signifikansi penelitian dengan taraf signifikansi sebesar 0,05

Berdasarkan perhitungan dari tabel diatas yang menunjukkan angka signifikansi sebesar 0,000< 0,05 maka dapat disimpulkan bahwasannya ada pengaruh yang signifikan dari budaya organsasi dan kompensasi terhadap kinerja pendidik. 


\section{PEMBAHASAN}

Penelitian ini bertujuan untuk mengetahui pengaruh budaya organisasi dan kompensasi terhadap kinerja pendidik di MA NU Mazro'atul Ulum Paciran. Proses pelaksanaan penelitian yang telah dilakukan oleh peneliti di MA NU Mazro’atul Ulum Paciran Lamongan berjalan dengan lancar sesuai dengan yang dirancang dan direncanakan peneliti.

gambaran pembahasan hasil penelitian dari masing-masing variabel yang bisa dideskripsikan sebagai berikut:

\section{Pengaruh Budaya Organisasi Terhadap Kinerja Pendidik}

Berdasarkan hasil analisis menunjukkan bahwa terdapat pengaruh budaya organsiasi terhadap kinerja pendidik di MA NU Mazro’atul Ulum Paciran, yaitu sebesar 77\%. Dan didasarkan pada hasil penghitungan menggunakan SPSS versi 24 menunjukkan angka t penelitian sebesar $6,440>\mathrm{t}$ tabel sebesar 2,068.

\section{Pengaruh Kompensasi Terhadap} Kinerja Pendidik

Berdasarkan hasil analisis menunjukkan bahwa tidak terdapat pengaruh kompensasi yang signifikan terhadap kinerja pendidik di MA NU Mazro'atul Ulum Paciran, yaitu sebesar 18,6\%. Dan didasarkan pada hasil penghitungan menggunakan SPSS versi 24 menunjukkan angka $\mathrm{t}$ penelitian sebesar $1,556<\mathrm{t}$ tabel sebesar 2,068 .

\section{Pengaruh Budaya Organisasi dan Kompensasi Terhadap Kinerja Pendidik}

Berdasarkan hasil analisis menunjukkan bahwa terdapat pengaruh yang secara bersamaan signifikan budaya organanisasi dan kompensasi yang signifikan terhadap kinerja pendidik di Madrasah Aliyah Nahdlatul Ulama Mazro'atul Ulum Paciran, yaitu sebesar 79,7\%. Dan didasarkan pada hasil penghitungan yang didapatkan menggunakan SPSS versi 24 menunjukkan $\mathrm{F}$ penelitian sebesar 43,099 > F tabel sebesar 3,44. 


\section{Kesimpulan}

Berdasarkan hasil analisis data pengaruh budaya organisasi dan kompensasi terhadap kinerja pendidik, maka dalam bab ini dapat disimpulkan:

Hasil analisa pengaruh budaya organsasi dan kompensasi terhadap kinerja pendidik yang telah dilakukan peneliti, dari hasil jawaban kuesioner yang telah disebarkan kepada 25 responden dengan menggunakan SPSS versi 24. Berdasarkan hasil uji koefisien determinasi $\left(\mathrm{R}^{2}\right)$ didapatkan $\mathrm{F}$ penelitian sebesar 43,099 > Ftabel sebesar 3,44 sehingga dapat disimpulkan bahwasannya ada pengaruh yang signifikan budaya organisasi $\left(\mathrm{X}_{1}\right)$ dan kompensasi $\left(\mathrm{X}_{2}\right)$ terhadap kinerja pendidik (Y). Besarnya pengaruh ialah 79,7\%. Besarnya pengaruh variabel lain diluar model tersebut sebesar $20,3 \%$.

Terdapat pengaruh yang signifikan dan positif, salah satu variabel bebas yang paling dominan terhadap kinerja pendidik, yaitu variabel budaya organisasi. Hasil ini diperoleh dari pengujian parsial (Uji t). Besarnya pengaruh budaya organisasi terhadap kinerja pendidik sebesar 77\%. Besarnya pengaruh kompensasi terhadap kinerja pendidik sebesar $18,6 \%$.

\section{Saran}

Bagi lembaga pendidikan yaitu MA NU Mazro'atul Ulum Paciran hendaknya mengevaluasi nilai budaya dan kompensasi supaya lebih baik lagi. Hal ini dilakukan agar memunculkan kinerja yang lebih baik terhadap pendidik.

Bagi tenaga pendidik, agar lebih meningkatkan kinerjanya dan juga mempunyai hubungan baik dengan sesama rekan kerjanya.

\section{Daftar Pustaka}

Aziz, abdul. Memahami Organisasi Pendidikan. Bandung: Alfabeta, 2013.

Crysoekamto, Asep Saifuddin dan Rudolf. Research Methodology: MODUL METPEN Pascasarjana IKHAC. Mojokerto: Institut $\mathrm{KH}$ Abdul Chalim, 2017.

Dessler, Gary. Manajemen Sumber Daya Manusia. 14th ed. Jakarta: salemba empat, 2017.

Haris, Ikhfan. Indeks Kinerja Sekolah. Yogyakarta: Penerbit Samudra Biru (Anggota IKAPI), 2016.

Hasibuan, Malayu. Manajemen Sumber Daya Manusia. Jakarta: Bumi Aksara, 2005. 
Ikhwani, Zain dan Eka Prihatin.

Pengaruh Kompensasi dan Iklim Orgnisasi Sekolah terhadap Kepuasan Kerja Guru non PNS Madrasah Aliyah. Bandung: Jurnal Administrasi Pendidikan. Vol. XXIII, No. 1 (2016): 12-25

Indrawijaya, Adam Ibrahim. Teori, Perilaku, Dan Budaya Organisasi. Bandung: PT Refika Aditama, 2010.

Jondar, Aloysius, Heri Sudarsono. Karakteristik Budaya Organisasi di Klinike Dr. Eko Surabaya. Surabaya: Jurnal Ilmiah Sosial dan Humaniora. Vol. 9, No. 1 (2015): 47-66

Mangkunegara, Anwar Prabu. Evaluasi Kinerja Sumber Daya Manusia. Bandung: Refika Aditama, 2007. - Perilaku Dan Budaya Organisasi. Cetakan Ke. Bandung: PT Refika Aditama, 2010.

Muhammad, Fadel. Reinventing Local Government: Pengalaman dari Daerah. Jakarta: Elex Media Komputindo, 2008.

Mulyadi, Harry. Hubungan Kepemimpinan dengan Kinerja Pegawai Dinas Pendidikan Kabupaten Pasaman. Padang: Jurnal Administrasi Pendidikan. Vol. 2, No. 1 (2014) : 302-831

Muslim. Kompetensi Guru, Budaya Organisasi, dan Pelayanan terhadap Kepuasan Orang Tua Murid pada Sekolah Menengah Atas Islam Hasmi Bogor. Bogor: Jurnal Manajemen Pendidikan Islam. Vol. I, No. 1 (2018): 44-69
Nuraisyah, Siti. Pengarub Kepemimpinan Kepala Sekolah, Budaya Organisasi dan Motivasi Kerja Guru Terbadap Kinerja Guru pada SMP Negeri di kecamatan Pandan Kabupaten Tapanuli Tengah Sumatera Utara. UT: Jurnal Bisnis dan Manajemen Ekskutif, Vol. 1, No. 1 (2014)

Ndraha, Taliziduhu. Budaya Organisasi. Jakarta: PT Rineka Cipta, 2004.

Pabundu. Budaya Organisasi Dan Peningkatan Kinerja Karyawan. Jakarta: Bumi Aksara, 2010.

Purwanto, Edi. Metode Penelitian Kuantitatif. Semarang: Fakultas Ilmu Pendidikan Universitas Negeri Semarang, 2013.

Robirodia, Zain Ikhwani Jihadi, and Eka Prihatin. "Pengaruh Kompensasi Dan Iklim Organisasi Sekolah Terhadap Kepuasan Kerja Guru Non PNS Madrasah Aliyah." Jurnal Administrasi Pendidikan 23, no. 1 (2016): 12-25.

Sarasasti. "Usaha Pengawas Dan Kepala Sekolah Dalam Meningkatkan Kinerja Guru PAI Di Madrasah Kota Solok." Jurnal Al-Fikrah 3, no. 1 (2015): 12-21.

Sagala, Syaiful. Manajemen Strategik dalam Peningkatan Mutu Pendidikan. Bandung: ALFABETA, 2013.

Sarwono, Jonathan. Analisis Jalur Untuk Riset Bisnis Dengan SPSS. Yogyakarta: CV Andi ffset, 2007. Sedarmayanti. Manajemen Sumber Daya Manusia. Bandung: Refika Aditama, 2011. 
Sobirin, Achmad. Budaya Organisasi, Pengertian, Makna dan Aplikasinya dalam Kebidupan Organisasi. Jakarta: Unit Penerbit STM YPKN, 2013.

Soetopo, Hendyat. Perilaku Organisasi. Bandung: PT Remaja Rosdakarya, 2016.

Sobirin, Achmad. Budaya Organisasi, Pengertian, Makna Dan Aplikasinya Dalam Kehidupan Organisasi. Jakarta: Unit Penerbit STM TPKN, 2013.

Sugiyono. Metode Penelitian Pendidikan. Cetakan Ke. Alfabeta, 2015.

Suharsimi, Arikunto. Prosedur Penelitian Suatu Pendekatan Praktek. Jakarta: PT. Rineka Cipta, 2002.

Triatna, Ceci. Prilaku Organisasi Dalam Pendidikan. Bandung: PT Remaja Rosdakarya, 2015.

Uha, Ismail Nawawi. Budaya Organisasi Kepemimpinan Dan Kinerja. Depok: N-Malang Pers, 2008.
KENCANA, 2017.

Usman Fauzi. "Pengaruh Kompensasi Terhadap Kinerja Karyawan Pada PT Trakindo Utama Samarinda." eJournal Ilmu Administrasi Bisnisournal Ilmu Administrasi Bisnis 2, no. 3 (2014): 172-85.

Usmany, Tiara Putri. Dkk. Pengaruh Budaya Organisasi Terbadap Komitmen Organisasional dan Kinerja Karyawan. Malang: Jurnal Administrasi Bisnis. Vol. 37, No. 2. (2016)

Wardani, Rodiatul Kusuma, dkk. Pengaruh Budaya Organisasi terbadap Kinerja Karyawan. Malang: Jurnal Administrasi Bisnis. Vol. 31, No. 1(2016) : 58-64

Wibowo. Manajemen Kinerja. Jakarta: PT Raja Grafindo Persada, 2012.

Yasin, A. Fatah. Dimensi-Dimensi Pendidikan Islam. malang: UI 